\title{
TARBAWI
}

Volume 3 No.2, Juli-Desember 2018

p-ISSN : 2527-4082, e-ISSN : 2622-920X

\section{Pengaruh Kualifikasi Akademik dan Prestasi Akademik Dosen Terhadap Mutu Pembelajaran}

\section{Effect of Lecturer's Academic Qualification and Academic Achievements on Learning Quality}

\author{
Amirah Mawardi ${ }^{1}$, Syarifuddin Ondeng ${ }^{2}$, Muh. Sain Hanafy ${ }^{3}$, Muhammad Yaumi $^{4}$ \\ ${ }^{*}$ amirahmawardi@yahoo.co.id |Universitas Muhammadiyah Makassar \\ ${ }^{*}$ Universitas Islam Negeri Alauddin Makassar \\ ${ }^{*}$ Universitas Islam Negeri Alauddin Makassar \\ ${ }^{*}$ Universitas Islam Negeri Alauddin Makassar
}

\begin{abstract}
Abstrak
Jenis penelitian ini adalah penelitian kuantitatif dengan pendekatan metodologis bercorak positivistic dan pendekatan ilmiah yang meliputi pendekatan pedagogis, psikologis, dan sosiologis. Responden dalam penelitian ini adalah dosen unismuh Makassar yang berjumlah 83 orang dengan teknik pengambilan sampel secara purposive(Purposive Sampling) Metode pengumpulan data yang digunakan adalah observasi, dokumentasi dan koesioner. Teknik pengolahan data dilakukan melalui analisis deskriptik dan analisis linear berganda.

Hasil penelitian yang diperoleh adalah : 1) Tingkat Kualifikasi akademik Dosen di Unismuh Makassar berkategori baik dengan indicator jenjang pendidikan (74,7\%), penguasaan materi (79,55), metode (73,1\%), media dan sumber belajar (92,8\%), dan kemampuan interaksi edukasi dalam proses belajar mengajar (98,8\%) 2 2) Tingkat Prestasi Akademik Dosen di Unismuh Makassar berdasarkan indikator. kemampuan lisan, kemampuan tulisan, keterampilan, dan kemampuan pemecahan masalah berada pada kategori sedang. 3) Mutu Pembelajaran di Unismuh Makassar berdasarkan indicator input, proses, out put dan outcome berada pada kategori tinggi. 4) Tidak terdapat pengaruh yang signifikan kualifikasi akademik terhadap mutu pembelajaran di unismuh Makassar terbukti dari nilai signifikansi 0, 502 < 1,66 yang artinya H1 ditolak dan $\mathrm{HO}$ diterimah. 5) terdapat pengaruh yang signifikan prestasi akademik dosen terhadap mutu pembelajaran dengan nilai 0,003 0,05 yang berarti $\mathrm{HO}$ ditolak dan HI diterimah.dengan demikian terdapat pengaruh antara 2 (dua) variable. 6) Terdapat pengaruh antara kualifikasi Akademik dan Prestasi akademik Dosen secara bersama sama terhada mutu pembelajaran di Unismuh Makassar . hal ini terlihat dari F hitung yang diperoleh sebesar 6, 130 sedang $F$ tabel sebesar 3,11. Ini menyatakan bahwa $F$ hitung $>F$ tabel, berarti nilai signifikan lebih kecil dari nilai probabilitas $(0,03<0$, 05) yang berarti bahwa kualifikasi akademik dan perstasi akademik Dosen secara simultan berpengaruh signifikan terhadap mutu pembelajaran di Unismuh Makassar.
\end{abstract}

Kata Kunci: Pengaruh kualifikasi, Prestasi Akademik, Mutu Pembelajaran 


\section{Abstract}

The type of this study is quantitative research with a positivistic methodological and scientific approach that includes pedagogical, psycological, and sociological approaches. The respondents of this study consisted of 83 Unismuh Makassar Lecturers. The sample was taken by purposive sampling technique. The data collection methods used were observation, documentation and questionnaires. The data was analyzed by using descriptive and multiple linear analysis.

The result of the study showed: 1) the academic qualification level of lecturers in UNISMUH Makassar in good category with education level indicators (74.7\%), mastery of material (79.55), teaching method (73.1\%), media and learning resources (92.8\%), and educational interaction skills in the teaching and learning process (98.8\%). 2) The Academic Achievement of lecturers in Unismuh Makassar based on indicators; oral and writing ability, skills, and problem solving abilities are in the medium category. 3) The Learning Quality in Unismuh Makassar based on input, process, output and outcome are in high category. 4) There is no significant effect of academic qualification on the learning quality in Unismuh Makassar as evidenced by the significance value of $0,502<1,66$ which means $\mathrm{H} 1$ is rejected and $\mathrm{H} 0$ is accepted. 5) There is a significant effect of lecturers' academic achievement on the learning quality with a value of $0,003<0,05$, which means that $\mathrm{H} 0$ is rejected and $\mathrm{H} 1$ is accepted. Therefore, there are the influences between two variables. 6) There is an effect between Academic qualifications and Academic Achievement of lecturers are jointly affected by the quality of learning in Unismuh Makassar. This can be seen from the F count obtained for 6.130 while $\mathrm{F}$ table is 3.11. This reveals that $\mathrm{F}$ count $>\mathrm{F}$ table which means that the lecturers' academic qualifications and achievement have a significant effect on the quality of learning in Unismuh Makassar.

\section{Keywords: Effect of qualitifications, Academic Achievement, Learning Quality}

\section{PENDAHULUAN}

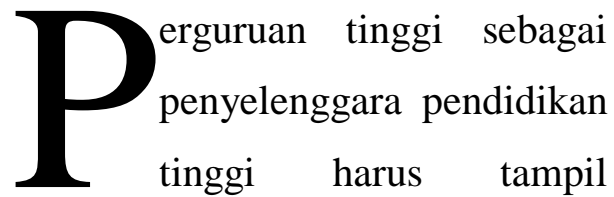

sebagai leader yang dapat diandalkan

dalam pengembangan kemajuan dan peradaban bangsa. Di samping itu perguruan tinggi mempunyai misi yang bersifat nasional dan merupakan infrastruktur untuk melahirkan lulusan atau calon pemimpin bangsa yang berkualitas dan berbudi luhur. Salah satu komponen penting dalam proses pendidikan tinggi adalah sumber daya manusia (SDM) Menyadari pentingnya proses peningkatan kualitas sumber daya manusia, maka pemerintah bersama kalangan swasta bersama-sama telah dan terus berupaya mewujudkan amanat tersebut melalui berbagai usaha pembangunan pendidikan yang lebih berkualitas antara lain melalui pengembangan dan perbaikan kurikulum dan sistem evaluasi, perbaikan sarana dan prasarana pendidikan, pengembangan dan pengadaan materi ajar, serta pelatihan bagi guru, dan tenaga kependidikan lainnya termasuk di dalamnya dosen sebagai salah satu tenaga kependidikan di perguruan tinggi. Salah satu bentuk upaya pengembangan SDM adalah dengan upaya pengembangan akademik melalui penguatan kapasitas dosen pada perguruan tinggi. 
Dalam penyelenggaraan Tridharma Perguruan Tinggi, dosen melaksanakan tiga jenis kegiatan yaitu: pendidikan/ pengajaran, penelitian, dan pengabdian kepada masyarakat. Pada dasarnya bidang utama kegiatan dosen adalah melaksanakan pendidikan dan pengajaran. Namun demikian, kegiatan penelitian dan pengabdiaan masyarakat berupa pelayanan (service) yang diberikan secara langsung kepada masyarakat, baik berbentuk skill, kebutuhan dasar, dan berbagai pencerahan yang dibutuhkan dalam rangka mencerdaskan kehidupan masyarakat, juga wajib dilaksanakan oleh seorang dosen. Kedua kegiatan ini akan sangat menunjang kegiatan pendidikan dan pengajaran yang lebih baik.

UU RI. No 14 tahun 2005 tentang guru dan dosen menyebutkan, dosen adalah pendidik profesional dan ilmuwan dengan tugas utama mentransformasikan, mengembangkan, dan menyebarluaskan ilmu pengetahuan, teknologi, dan seni melalui pendidikan, penelitian, dan pengabdian kepada masyarakat (Bab 1 Pasal 1) Sebagai pekerjaan profesional, dosen dituntut memiliki sejumlah kompetensi agar dapat melaksanakan tugasnya dengan baik yakni sebagai seorang pengajar profesional. Salah satu bentuk keprofesionalan dosen adalah memiliki kualifikasi akademik dan prestasi akademik sesuai aturan yang dipersyaratkan dalam UU RI. No 14 tahun 2005 tentang guru dan dosen, Peraturan Pemerintah (PP) RI No 32 tahun 2013 tentang Standar Nasional Pendidikan serta diperkuat oleh Permendiknas No 49 tahun 2014 tentang Standar Nasional Pendidikan Tinggi. Selanjutnya di Permendiknas Nomor 49 Tahun 2014 Pasal 46 ayat 1 dan 2 disebutkan: Ayat 1: "Kualifikasi akademik dosen sebagaimana dimaksud dalam Pasal 45 diperoleh melalui pendidikan tinggi program pascasarjana yang terakreditasi sesuai dengan bidang keahlian". Ayat 2: Dosen memiliki kualifikasi akademik minimum: (1) Lulusan program magister untuk program diploma atau program sarjana; dan (2) Lulusan program doktor untuk program pascasarjana.

Prestasi akademik merupakan perubahan dalam hal kecakapan tingkah laku, ataupun kemampuan yang dapat bertambah selama beberapa waktu dan tidak disebabkan proses pertumbuhan, tetapi adanya situasi belajar. Perwujudan bentuk hasil proses belajar tersebut dapat berupa kemampuan lisan maupun tulisan, dan keterampilan serta kemampuan pemecahan masalah secara langsung yang dapat diukur atau dinilai dengan menggunakan tes yang berstandar. 
Dosen merupakan komponen penting dalam pendidikan tinggi, apapun kebijakan peningkatan mutu pendidikan yang dirancang pada akhirnya dosen yang melaksanakan dalam proses belajar mengajar (PBM). Mutu pembelajaran sangat tergantung dari kemampuan akademik dan komitmen dosen untuk mengembangkan kompetensinya. Secara luas pengertian mutu pembelajaran di perguruan tinggi dapat mencakup berbagai aspek yang antara lain meliputi saranaprasarana, tatanan organisasi, sistem manajemen, kualifikasi tenaga pendidik/dosen dan tenaga kependidikan/non-dosen, input/peserta didik, proses pembelajaran, dan output atau kualifikasi lulusan/keluaran yang dapat memuaskan pelanggan atau masyarakat dan pengguna jasa pendidikan dan outcome (efek jangka panjang dari proses pendidikan)

Mutu dalam konteks manajemen mutu terpadu atau Total Quality Management (TQM) bukan hanya suatu gagasan, tetapi suatu filosofi dan metodologi untuk membantu lembaga dalam mengelola perubahan secara sistematik dan totalitas, melalui suatu perubahan visi, misi, nilai, serta tujuan.

Mutu di bidang pendidikan meliputi 4 yaitu: input, proses, output, dan outcome, yaitu:
1. Input pendidikan dinyatakan bermutu apabila telah berproses.

2. Proses pendidikan bermutu jika mampu menciptakan suasana yang aktif, kreatif dan juga menyenangkan.

3. Output dinyatakan bermutu jika hasil belajar dalam bidang akademik dan non akademik peserta didik tinggi.

4. Outcome dinyatakan bermutu apabila lulusan cepat terserap di dunia kerja, gaji yang wajar, dan semua pihak mengakui kehebatannya lulusannya dan merasa puas.

Peraturan Menteri Pendidikan Nasional (Permendiknas) Republik Indonesia Nomor 49 Tahun 2014 tentang Standar Nasional Pendidikan Tinggi antara lain menuntut dosen untuk memiliki standar kompetensi secara nasional yang dikenal dengan Standar Nasional Pendidikan Tinggi. Kualifikasi dosen yang dimaksud adalah dosen wajib memiliki kualifikasi akademik, kompetensi, sertifikat pendidik, sehat jasmani dan rohani, dan memenuhi kualifikasi lain yang dipersyaratkan satuan pendidikan tinggi tempat bertugas, serta memiliki kemampuan untuk mewujudkan tujuan pendidikan nasional. 
Keunggulan bersaing merupakan kemampuan organisasi untuk tumbuh dan berkembang di berbagai persaingan. Keunggulan bersaing perguruan tinggi saat ini sangat diperlukan baik pada percaturan nasional maupun global. Perguruan tinggi di Indonesia pada tahun 2017 yang terdaftar mencapai 4.504 perguruan tinggi yang terdiri dari 3.136 buah perguruan tinggi swasta (PTS) dan 122 buah perguruan tinggi negeri.

Sehubungan dengan itu maka keunggulan bersaing dosen melalui prestasi dan kualifikasi akademik di Universitas Muhammadiyah Makassar menjadi hal yang sangat urgen dan perlu ditingkatkan dengan melihat animo masyarakat yang tinggi untuk masuk ke perguruan tinggi. Selain itu perbaikan SDM setiap dosen perlu diperhatikan agar bisa bersaing dengan dosen yang ada di perguruan tinggi negeri dan swasta lainnya. Perguruan tinggi sebagai pencetak tenaga profesional selalu berusaha mengkaji masalah ini terus menerus terutama bagaimana daya saing dosen untuk meningkatkan mutu pembelajaran secara khusus dan mutu perguruan tinggi secara umum. Ancaman persaingan akan datang dari perguruan tinggi negeri dan swasta yang ada di Sulawesi Selatan. Hal ini terlihat bagaimana dosen di berbagai perguruan tinggi lainnya untuk membenahi
SDM agar dapat bersaing dan mendapatkan pengakuan di masyarakat tentang mutu perguruan tinggi termasuk Universitas Muhammadiyah Makassar.

Berdasarkan deskripsi di atas, dapat dikatakan bahwa kualifikasi akademik dan prestasi akademik dosen berpengaruh pada mutu pembelajaran, baik di tingkat prodi maupun di tingkat institusi. Dengan demikian bila keadaan perguruan tinggi dihadapkan dengan permasalahan di atas, maka akan mempengaruhi mutu pembelajaran, untuk itu, dipandang perlu melakukan kajian tentang kualifikasi dan prestasi akademik dosen terhadap mutu pembelajaran di Universitas Muhammadiyah Makassar.

\section{METODOLOGI PENELITIAN}

Jenis penelitian yang digunakan bersifat deskriptif kuantitatif, untuk mengungkapkan fakta yang berkaitan dengan pengaruh kualifikasi akademik dan prestasi akademik dosen terhadap mutu pembelajaran di Universitas Muhammadiyah Makassar yang mengakomodasi bentuk angka-angka dalam pengolahan data statistik. Dalam penelitian ini terdapat dua variabel yakni variabel bebas, yaitu kualifikasi akademik dan prestasi akademik dosen dan satu variabel terikat yaitu Mutu pembelajaran. Lokasi yang dijadikan sebagai objek 
penelitian dalam pengumpulan data dalam penelitian ini adalah Universitas Muhammadiyah Makassar. Terkait dengan lokasi penelitian, setelah melakukan observasi awal sebagai studi pendahuluan, peneliti memilih di Unismuh Makassar sebagai lokasi penelitian dengan pertimbangan, karena peneliti mengabdi dan bertugas di Unismuh Makassar.

Pendekatan dalam penelitian ini terdiri dari dua, yaitu pendekatan metodologis dan pendekatan ilmiah. Pendekatan metodologis yang digunakan ialah pendekatan yang bercorak positivistic. Populasi dalam penelitian disertasi ini adalah seluruh dosen yang mengabdi di Universitas Muhammadiyah Makassar sebanyak 668 orang dan Sampel dalam penelitian ini diambil $10 \%$ dari jumlah populasi atau dosen yang ada di Unismuh Makassar yakni sebanyak 83 orang sampel yang tersebar pada 6 fakultas. Sedangkan metode pengumpulan data ialah observasi, dokumentasi dan kuesioner. untuk instrument penelitian ialah angket, observasi dan dokumentasi.

\section{PEMBAHASAN}

\section{Tingkat Kualifikasi Akademik Dosen} di Universitas Muhammadiyah Makassar

Kualifikasi mendorong seseorang untuk memiliki suatu "keahlian atau kecakapan khusus". Dalam dunia pendidikan, kualifikasi dipahami sebagai keahlian atau kecakapan khusus dalam bidang pendidikan, baik sebagai pengampuh mata kuliah/mata pelajaran, administrator pendidikan dan seterusnya. Bahkan, kualifikasi terkadang dapat dilihat dari segi derajat lulusannya.

Kajian kualifikasi akademik dalam penelitian ini diarahkan pada kompetensi dosen yang mencakup jenjang pendidikan, kompetensi penguasaan materi, metode, media dan sumber belajar, kemampuan menciptakan pola interaksi edukatif dalam proses pembelajaran.

Penjelasan tentang dosen berdasarkan kualifikasi akademik sebagai berikut:

\section{a. Jenjang Pendidikan}

Universitas Muhammadiyah Makassar sebagai lembaga pendidikan tinggi berkewajiban melaksanakan Tri Darma Perguruan Tinggi, bahkan di Unismuh Makassar memiliki Catur Darma, yakni melaksanakan pendidikan, penelitian, pengabdian pada masyarakat, serta pembinaan AlIslam Kemuhammadiyahan. Untuk melaksanakan Catur Darma pertama, maka diperlukan kualifikasi jenjang pendidikan untuk mendukung kualitas pelaksanaan pendidikan. 
Untuk memenuhi tagihan berpendidikan S3 sebanyak 130 orang kualifikasi jenjang pendidikan pada sebuah lembaga pendidikan tinggi tentu membutuhkan waktu dan biaya yang signifikan, termasuk di Unismuh (20\%) dengan rincian sebagai berikut:

\section{Tabel 1. Kualifikasi Akademik Dosen Unismuh Makassar Berdasarkan Jenjang Pendidikan}

\begin{tabular}{|c|c|c|c|c|c|}
\hline Makassar. Ada dosen & No & FAKUITAS & & TRA & \\
\hline memperolehnya dengan melanju & & & S2 & S3 & Jumlah \\
\hline studi lanjut menggunakan fasi & 1 & FKIP & 216 & 38 & 252 \\
\hline beasiswa kementrian terkait, dan & 2 & FAI & 55 & 16 & 71 \\
\hline juga yang diberi bantuan studi la & 3 & Pertanian & 46 & 20 & 66 \\
\hline oleh Unismuh Makassar be & 4 & Teknik & 55 & 10 & 65 \\
\hline pembayaran SPP selama tiga to & 5 & Fisipol & 32 & 25 & 57 \\
\hline masa studi, biaya penelitian & 6 & Kedokteran & 55 & 3 & 58 \\
\hline nromosi untuk kualifikasi 33 & 7 & FEBIS & 80 & 19 & 99 \\
\hline Terkait dengan vari & & JUMLAH & 538 & 130 & 668 \\
\hline
\end{tabular}

kualifikasi akademik terdiri dari indikator pertama yakni jenjang pendidikan, di mana rata rata jenjang pendidikan dosen di Universitas Muhammadiyah Makassar berada pada kategori memenuhi syarat akademik yang ditentukan oleh UU Sisdiknas 2003 dan UU RI nomor 14 tahun 2005 tentang guru dan dosen. Pemenuhan kebutuhan dosen di Unismuh Makassar menurut variabel kualifikasi akademik dapat dibuktikan dengan data jenjang pendidikan yang menunjukkan bahwa dari 668 orang jumlah dosen di Universitas Muhammadiyah Makassar yang tersebar di 7 (tujuh) fakultas, jumlah dosen yang berpendidikan $\mathrm{S} 2$ sebanyak 538 orang $(80 \%)$ dan yang

\section{b. Penggunaan Media dan Sumber}

\section{Belajar}

Pada variabel penggunaan media dan sumber belajar menunjukkan bahwa 92,8\% dosen di Universitas Muhammadiyah Makassar menggunakan sumber dan media pembelajaran. Hal ini menunjukkan bahwa rata rata dosen di Unismuh Makassar dalam penggunaan media dan sumber belajar sudah memadai.

\section{c. Kemampuan Interaksi Edukatif}

Pada variabel interaksi eduktif dosen dalam Proses Belajar Mengajar (PBM), dari keempat item atau pernyataan yang meliputi: menciptakan suasana pembelajaran 
yang aktif menyenangkan, memberikan kesempatan berdialog kepada mahasiswa dalam perkuliahan,memberikan solusi terhadap masalah yang dihadapi mahasiswa, memberi kesempatan kepada mahasiswa untuk mengemukakan pendapat menunjukkan bahwa indikator kemampuan interaksi edukatif dosen dalam Proses Belajar Mengajar di Universitas Muhammadiyah Makassar sangat baik.

\section{Tingkat Prestasi Akademik Dosen di}

\section{Universitas Muhammadiyah Makassar}

Prestasi akademik merupakan perubahan dalam hal kecakapan tingkah laku, ataupun kemampuan yang dapat bertambah selama beberapa waktu yang tidak disebabkan proses pertumbuhan tetapi adanya situasi belajar. Selain pendidikan formal, Universitas Muhammadiyah Makassar juga telah melakukan pemberdayaan Sumber Daya Manusia dalam bentuk pembinaan internal dan eksternal. Pembinaan internal seperti; memberikan kepercayaan kepada dosen untuk menduduki jabatan struktural sebagai Rektor, Wakil Rektor, Dekan, Wakil Dekan dan Ketua Program Studi. Pembinaan Eksternal, dalam bentuk pemberian rekomendasi kepada dosen untuk mengikuti studi lanjut S2 dan S3. Selain itu, para dosen juga diutus untuk mengikuti berbagai seminar, penataran, pelatihan dan pertemuan ilmiah serta kegiatan pengabdian masyarakat, baik di dalam maupun di luar negeri, seperti; Pelatihan Peningkatan Kinerja Program Studi, Pelatihan Internal Quality Audit, Pelatihan Integrasi Sistem Penjaminan Mutu Perguruan Tinggi (SPMPT) di UGM, Sistem Manajemen Mutu (SMM) di UMY, Pelatihan Sistem Penjaminan Mutu Perguruan Tinggi di UM Sidoarjo, Pelatihan Sistem Penjaminan Mutu Perguruan Tinggi di UII, dan Audit Mutu Akademik Internal (AMAI) di UGM dan UMY.

Pembinaan kemampuan peneliti, dengan mengikutsertakan dosen dalam pelatihan metodologi penelitian dan pemberian bantuan dana penelitian dan pengabdian kepada masyarakat. Pembinaan tenaga kependidikan dalam meningkatkan keterampilan dan wawasan, dengan mengikutsertakan dalam berbagai pelatihan/training baik yang dilakukan oleh lembaga di dalam dan di luar kampus, seperti; pelatihan peningkatan mutu layanan, pelatihan keterampilan IT (Informasi Teknologi), pelatihan pengelolaan keuangan, dan pelatihan pengelolaan perpustakaan. 
Berkaitan pengembangan kompetensi Dosen dan tenaga kependidikan, Universitas Muhammadiyah Makassar telah memberi bantuan beasiswa studi lanjut ke jenjang pendidikan S2 dan S3, baik untuk dosen maupun tenaga kependidikan (tenaga administrasi, pustakawan, teknisi dan laboran) Hal ini dituangkan dalam SK Rektor dan diatur dalam Peraturan Kepegawaian No. 124 Tahun 1427 H/2006 M, Pasal 20 Tentang Pendidikan Lanjut. Pemberian bantuan studi lanjut bagi dosen Universitas Muhammadiyah Makassar Untuk program S2 dan S3 diatur dalam SK Rektor No. 100 Tahun 1431 H/2010 M Tentang Ketentuan Studi Lanjut Dosen. Bantuan beasiswa diharapkan dapat memotivasi dosen dan tenaga kependidikan dalam meningkatkan kapasitas, kualitas dan kompetensinya di dalam pengelolaan akademik di institusi Universitas Muhammadiyah Makassar.

$$
\text { Pencapaian prestasi dosen }
$$
Universitas Muhammadiyah Makassar dapat diukur dari prestasi pelaksanaan Catur Darma yang meliputi bidang pendidikan, penelitian dan pengabdian kepada masyarakat dan pembinaan AlIslam Kemuhammadiyahan.

\section{a. Prestasi Bidang Pendidikan}

Pendidikan atau pembelajaran adalah proses interaksi antara mahasiswa dengan dosen dan sumber belajar pada suatu lingkungan belajar. Prestasi dosen Unismuh Makassar di bidang pendidikan/akademik dapat diukur dari kemampuan lisan, kemampuan tulisan, keterampilan, pencapaian reputasi/prestasi akademik, kemampuan pemecahan masalah (Hasil prestasi akademik dosen yang berpengaruh langsung kepada mutu pembelajaran dapat dibuktikan dengan peningkatan Indeks Prestasi Kumulatif dan lama studi mahasisiswa setiap tahun akademik (instrument out put pada angket penelitian)

Hal lain yang berkaitan dengan prestasi akademik dosen adalah:

1. Peningkatan jabatan pangkat akademik dosen ke lektor, lektor kepala, dan Guru Besar. Dari 668 dosen Unismuh Makassar terdapat 5 orang $(0.75 \%)$ Guru Besar, 79 orang (11,83\%) lektor Kepala, 92 orang (13,78\%) lektor 214 orang (32, $1 \%$ ) Asisten Ahli dan sisanya tenaga pengajar yang merupakan dosen baru dan sementara proses pengurusan pangkat akademik.

2. Bertambahnya jumlah dosen yang meraih gelar doktor pada tahun 2018 Hingga sekarang ini jumlah doktor di Unismuh Makassar sebanyak 130 orang. 
3. Tahun $2017 / 2018$ jumlah dosen yang lanjut studi S3 sebanyak 41 orang, sehingga jumlah keseluruhan dosen yang sementara lanjut dan proses penyelesaian S3 sampai tahun akademik 2017/2018 adalah sebanyak 105 orang.

4. Perekrutan dosen baru tahun 2017 sebanyak 149 orang.

5. Pemberian bantuan biaya pendidikan dan bantuan biaya penyelesaian S3 bagi dosen tetap yang lanjut studi.

Berdasarkan data dari berbagai sumber terutama dari beberapa borang akreditasi program studi di Unismuh Makassar pada standar 4.5, didapatkan bahwa rata rata dosen di Unismuh Makassar memiliki reputasi dan prestasi akademik dosen yang baik. Hal tersebut diperkuat oleh hasil temuan penulis berdasarkan Indikator variabel tentang prestasi dosen yang meliputi: kemampuan lisan (kategori rata-rata sering) kemampuan tulisan (berkategori kadang dan sering) keterampilan (berkategori selalu dan sering), pencapaian prestasi/reputasi akademik (berkategori sering dan kadang), kemampuan pemecahan masalah (berkategori selalu dan sering)

\section{b. Prestasi Bidang Penelitian dan Pengabdian Masyarakat}

Penelitian adalah kegiatan yang dilakukan menurut kaidah dan metode ilmiah secara sistematis untuk memperoleh informasi, data, dan keterangan yang berkaitan dengan pemahaman dan/atau pengujian suatu cabang pengetahuan dan teknologi. Sedangkan Pengabdian kepada masyarakat adalah kegiatan civitas akademika yang memanfaatkan ilmu pengetahuan dan teknologi untuk memajukan kesejahteraan masyarakat dan mencerrdaskan kehidupan bangsa. Berdasarkan data tentang hasil penelitian dan Pengabdian Kepada Masyarakat (PKM) dosen di Unismuh Makassar dapat dilihat dalam tabel berikut ini:

\section{Gambar 1. Penelitian Internal dan Penelitian Dikti}

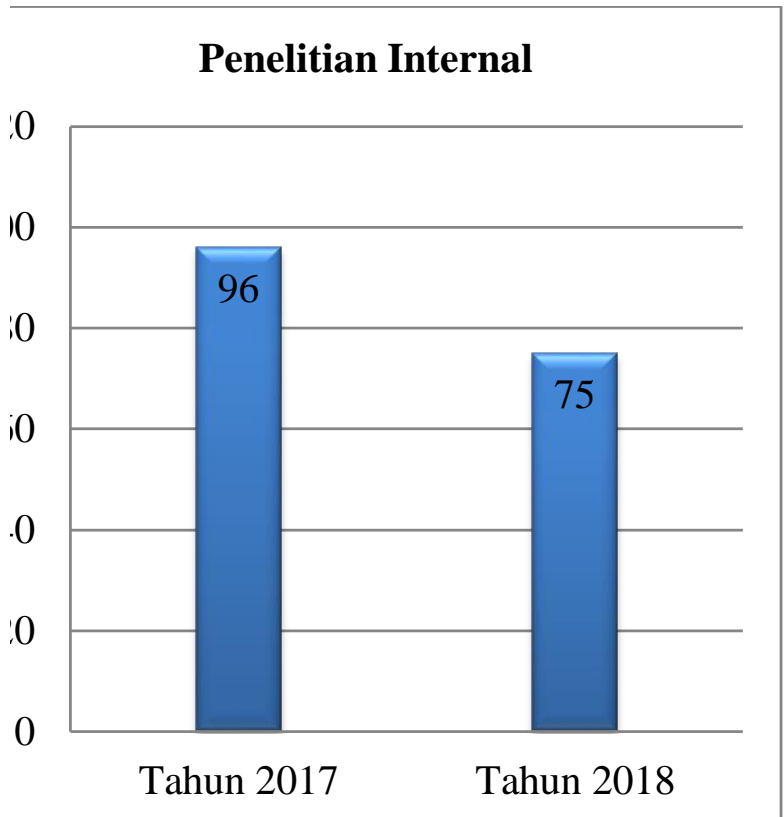




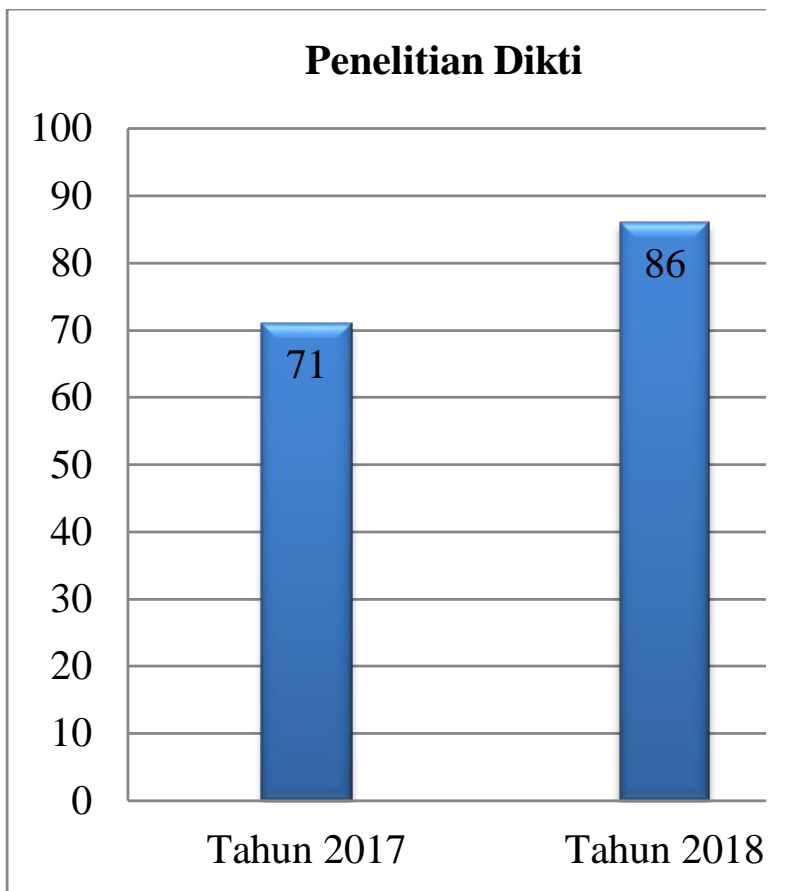

Sumber Data: Laporan Rektor

Berdasarkan data tersebut dapat diketahui bahwa prestasi akademik dosen Unismuh Makassar di bidang penelitian dan pengabdian kepada masyarakat cukup tinggi.

\section{c. Program Pembinaan Al-Islam}

\section{Kemuhammadiyahan (AIK)}

Pembinaan

Al-Islam

Kemuhammadiyahan adalah sebuah program yang berupaya melakukan pembinaan dan pengembangan Al-Islam Kemuhammadiyahan dalam lingkungan Unismuh Makassar melalui perkuliahan dan kegiatan ciri khusus lainnya. Bentukbentuk pembinaan AIK sebagai berikut:

1) Penyusunan Kurikulum AIK

2) Program kampus bebas rokok.

3) Gerakan Shalat berjamaah di Mesjid Kampus.
4) Gerakan shalat subuh berjamaah.

5) Gerakan Jamaan Dakwah Jamaah (GJDJ).

6) Pelatihan Muballigh Hijrah Unismuh Makassar

7) Pengajian tujuh menit (kultum) yang dilakukan usai shalat dhuhur berjamaah di masjid Kampus Unismuh Makassar,

8) Kajian ketarjihan Muhammadiyah setiap bulan suci Ramadhan.

9) Sarasehan dan Sosialisasi Pengembangan Pengelolaan Asrama dan Ma'had PTM yang diselenggarakan oleh Majelis Dikti Litbang PP Muhammadiyah Kerjasama dengan Unismuh Makassar.

10) Pelaksanaan kegiatan Regional Meeting Lembaga Pengembangan Cabang dan Ranting (LPCR) Muhammadiyah se Indonesia.

11) Program Tahsiinul Qira'ah AlQuran 3x sepekan di seluruh unit kerja di Unismuh Makassar.

12) Program Pendidikan Ulama Tarjih

13) Baitul Arqam Dosen.

14) Pelatihan Perawatan Jenazah.

15) Pelatihan Metode Hisab \& Rukyah Bentuk pembinaan dan pengembangan Al-Islam Kemuhammadiyahan tersebut merupakan penjabaran dari Catur Darma Unismuh 
Makassar yang keempat karena merupakan manivestasi dari amanah Persyarikatan Muhammadiyah kepada Perguruan Tinggi Muhammadiyah.

\section{Mutu Pembelajaran di Universitas} Muhammadiyah Makassar

Universitas Muhammadiyah

Makassar telah memiliki dokumen lengkap terkait sistem monev kinerja dosen dan tenaga kependidikan, serta tenaga pendukung lainnya yang dilaksanakan secara konsisten dan berkesinambungan. Berkaitan dengan pelaksanaan monev dan rekam jejak kinerja akademik, Universitas Muhammadiyah Makassar telah membentuk salah satu lembaga yang dinamakan P4M yang saat ini dikenal dengan nama lembaga QA (Quality Assurance), berfungsi menciptakan, melaksanakan dan mendorong pelaksanaan peningkatan mutu proses pembelajaran.

Lembaga Penjaminan

Mutu/Quality Assurance (LPM/QA) memiliki tugas pokok mengkaji sistem mutu di bidang pendidikan, penelitian dan pengabdian masyarakat serta kemahasiswaan. Dalam melaksanakan tugasnya, P4M bekerjasama dengan Unit Penjamin Mutu (UPM) di tingkat Fakultas dan Gugus Kendali Mutu (GKM) di tingkat program studi.
Sejak tahun 2011 LPM telah mengembangkan sistem mutu yang meliputi bidang akademik dan pengelolaan program studi. Prosedur mutu ini secara periodik dimonitoring pelaksanaannya melalui kegiatan Audit Mutu Internal (AMI) Beberapa hasil pengembangan yang telah digunakan oleh institusi adalah kurikulum KBK, KKNI, sistem akademik, lesson studi dan e-learning, panduan penulisan skripsi dan tesis, PPL, PKM, PKL, P2K dan KKN Profesi. Sistem pembelajaran dibangun berdasarkan perencanaan yang relevan dengan tujuan ranah belajar dan hierarkinya. Pembelajaran dilaksanakan menggunakan berbagai strategi dan teknik yang menantang dan mendorong mahasiswa untuk berpikir kritis, bereksplorasi, berkreasi dan bereksprimen dengan memanfaatkan aneka sumber. Pelaksanaan pembelajaran memiliki mekanisme untuk memonitor, mengkaji, dan memperbaiki secara periodik kegiatan perkuliahan (kehadiran dosen dan mahasiswa), penyusunan materi perkuliahan, serta penilaian hasil belajar.

Sistem pengendalian mutu proses pembelajaran mengacu kepada kebijakan akademik dan peraturan akademik Universitas Muhammadiyah Makassar, Visi dan Misi Universitas, Visi dan Misi Fakultas, serta Visi dan Misi Program 
Studi. Sistem pengendalikan mutu proses pembelajaran di Universitas Muhammadiyah Makassar dilakukan oleh P4M dan UPM di tingkat Fakultas dengan penerapan Sistem Penjaminan Mutu Internal (SPMI). Sistem pengendalian mutu proses pembelajaran meliputi empat elemen, yaitu:

1) Kebijakan mutu.

2) Standar mutu.

3) Manual mutu, dan.

4) Manajemen Mutu

Di tingkat institusi, ada empat unit kerja yang berfungsi melaksanakan Monev dosen dan tenaga kependidikan, yaitu:

a) LPM (Lembaga Penjminn Mutu) di tingkat universitas, salah satu fungsinya adalah memonitor dan mengevaluasi kinerja sumber daya manusia (SDM), seperti; kedisiplinan, kehadiran dosen, dan lain-lain. Lembaga ini bersifat otonom dan dalam pelaksanaan tugasnya bertanggungjawab langsung kepada pimpinan universitas.

b) Unit Penjaminan Mutu (UPM) di tingkat fakultas, berfungsi memonitor dan mengevaluasi kinerja sumber daya manusia di tingkat fakultas, termasuk memonitoring proses pembelajaran, penelitian dan pengabdian masyarakat yang dilakukan dosen di tingkat fakultas. c) Unit Kendali Gugus Mutu (UKGM) di tingkat program studi, berfungsi memonitor dan mengevaluasi kinerja sumber daya manusia di program studi. Unit Kendali Gugus Mutu (UKGM) dalam menjalankan tugas dan fungsinya bersentuhan langsung dengan dosen di program studi sebagai pengendali dalam memonitor dan mengevaluasi kegiatan pendidikan dan pengajaran, penelitian dan pengabdian masyarakat.

d) Biro administrasi umum, salah satu unit yang mempunyai tugas dan fungsi melakukan Monev kepada tenaga kependidikan dan tenaga pendukung lainnya.

Unit kerja di atas telah membuat instrument Monev yang tertuang dalam SOP dan dijalankan oleh masing-masing unit secara terintegrasi. Pelaksanaan Monev kinerja dan rekam jejak dosen dilakukan pada aspek Tridharma Perguruan Tinggi, yaitu pendidikan (akademik), penelitian dan pengabdian kepada masyarakat.

Sistem monitoring dan evaluasi kinerja dosen di masing-masing program studi dilakukan dengan cara:

(1) Kegiatan belajar mengajar (KBM); monitoring berupa dokumentasi proses pembelajaran, yang dibuktikan dengan berita acara perkuliahan. 
Evaluasi kegiatan belajar mengajar (KBM) dilakukan dengan menerima feedback dari mahasiswa berupa kuesioner penilaian kinerja yang dilakukan pada setiap akhir semester. Komponen yang dinilai adalah kesesuaian materi dengan GBPP, ketepatan memulai dan mengakhiri perkuliahan, metode pembelajaran, dorongan memotivasi.

(2) Kegiatan penelitian dan karya ilmiah serta pengabdian pada masyarakat, dimonitoring oleh program studi bekerjasama dengan Lembaga Penelitian, Pengembangan dan Pengabdian Masyarakat (LP3M). Evaluasi kegiatan penelitian dan karya ilmiah serta pengabdian pada masyarakat dilakukan secara rutin setiap tahun. Penghargaan akan diberikan kepada dosen dalam aktivitasnya berkaitan dengan penelitian dan pengabdian masyarakat.

(3) Kegiatan penunjang, dimonitoring oleh program studi dalam bentuk dokumentasi kegiatan penunjang yang dilakukan oleh masing-masing dosen di program studi. Evaluasi kegiatan penunjang dilakukan dalam rapat rutin program studi dan setiap partisipasi dalam kegiatan tersebut disediakan insentif dari universitas.
Pelaksanaan Monev untuk menilai kinerja dosen sebagai peneliti atau yang terlibat dalam kegiatan penelitian dan pengabdian kepada masyarakat menggunakan instrument yang telah dibuat LP3M secara terstruktur. Instrumen monev tersebut, antara lain; keikutsertaan/partisipasi dosen pada kegiatan penelitian, dan (2) keikutsertaan dosen dalam kegiatan pengabdian masyarakat. Pengumpulan data dari instrument tersebut kemudian dilaporkan kepada pimpinan universitas dalam bentuk laporan evaluasi yang disampaikan setiap akhir semester. Tindak lanjut hasil pelaksanaan Monev kemudian diputuskan melalui rapat koordinasi dengan pimpinan universitas yang dilaksanakan secara reguler.

Monev yang dilakukan pada dasarnya bukan bertujuan mencari kesalahan, tetapi lebih utama diharapkan agar program dapat terlaksana sesuai dengan perencanaan, lebih efektif dan efisien. Di samping itu, Monev dapat mendeteksi kesulitan dan/atau penyimpangan lebih awal, sehingga lebih mudah mengatasinya. Monev yang dilaksanakan Universitas Muhammadiyah Makassar selama ini terdiri dari tiga tahap; (1) monev diawal kegiatan, (2) monev saat kegiatan berlangsung, dan (3) monev diakhir kegiatan. Hal ini dimaksudkan 
untuk memperkecil ruang lingkup terjadinya kesalahan dan atau penyimpangan dalam pelaksanaan program/kegiatan tersebut.

Dalam rangka meningkatkan intensitas kinerja dosen dalam pelaksanaan kegiatan penelitian dan pengabdian masyarakat, Universitas Muhammadiyah Makassar melakukan; (1) pengawasan secara intensif melalui jalur structural (berjenjang), (2) pengawasan secara intensif dari pimpinan unit kerja yang bersangkutan, (3) tanggung jawab untuk menyelesaikan masalah yang dihadapinya, dan (4) intensitas rapat koordinasi baik di tingkat universitas maupun di tingkat fakultas dan program studi.

Hasil dan tindak lanjut dari sistem Monev untuk kinerja dosen dan tenaga kependidikan berupa; (1) aspek akademik untuk dosen yaitu adanya pelatihan perbaikan proses pembelajaran, pelatihan berbasis SCL, pelatihan penulisan proposal penelitian untuk para dosen yang kurang aktif dalam penelitian, dan lain-lain, (2) aspek non-akademik untuk dosen dan tenaga kependidikan dapat berupa; penghargaan bagi dosen dan tenaga kependidikan yang berprestasi dan pemberian sanksi jika terdapat pelanggaran sesuai dengan berat ringannya pelanggaran yang dilakukan.
Kehadiran dosen dan tenaga kependidikan di Universitas Muhammadiyah Makassar dimonitoring oleh seorang staf administrasi di tingkat program studi/fakultas, dengan menggunakan absensi. Absensi selain bertujuan mengevaluasi tingkat kehadiran dosen, juga digunakan sebagai dasar pembayaran lauk pauk bagi dosen yang berstatus Pegawai Negeri Sipil. Kehadiran dosen dalam proses pembelajaran dimonitoring dengan menggunakan format yang disiapkan oleh P4M. Evaluasi kehadiran dosen dilakukan program studi pada pertengahan dan menjelang akhir semester melalui rapat rutin di program studi. Selain itu, kehadiran dosen dalam proses pembelajaran dimonitoring oleh UPM melalui gugus kendali mutu di masing-masing fakultas. Selain aktivitas pembelajaran yang dimonitoring, aktivitas kegiatan penelitian dan pengabdian masyarakat juga dilakukan monitoring terhadap tenaga pendidik, melalui kerjasama antara P4M dan LP3M, serta pelaporan individu tenaga pendidik ke program studi, fakultas dan universitas.

Di akhir semester, setiap dosen wajib mengisi lembar beban kerja dosen (BKD) sebagai bahan evaluasi ketercapaian kinerja dosen dalam semester berjalan, meliputi; kegiatan pendidikan dan pengajaran, penelitian, pengabdian 
masyarakat dan kegiatan penunjang tri dharma perguruan tinggi. Setiap dosen harus memenuhi standar kinerja per semester sebesar 12 - 16 sks. Bagi dosen yang tidak memenuhi standar tersebut diberikan sanksi berupa pembatalan pembayaran tunjangan (kinerja, sertifikasi dan sebagainya)

Seluruh kegiatan monitoring dan evaluasi dilakukan berdasarkan pedoman dan aturan yang berlaku. Sistem monitoring dan evaluasi yang dilakukan terhadap dosen dan tenaga kependidikan, harus memenuhi kualifikasi akademik dan profesional yang ditandai dengan latar belakang pendidikan dan dibuktikan dengan ijazah, serta sertifikat kompetensi yang dipersyaratkan seperti yang tertuang dalam UU No 14 Tahun 2005 tentang guru dan dosen Pasal 45 dan 46 , Peraturan Pemerintah no. 19 Tahun 2005 tentang standar nasional pendidikan, Pasal 28 ayat (1) dan (2) dan memiliki mutu kinerja ditandai dengan tingkat jabatan akademik dan rekam jejak yang baik. Dalam rangka memudahkan monitoring dan evaluasi serta rekam jejak kinerja akademik dosen dan tenaga kependidikan, Universitas Muhammadiyah Makassar telah menciptakan sejumlah sistem informasi, terdiri dari; informasi data base yang terintegrasi dan berfungsi sebagai sarana dalam membantu proses administrasi kepegawaian, penilaian kinerja, serta membantu proses pengambilan keputusan ditingkat manajemen.

Standar Mutu Akademik Universitas Muhammadiyah Makassar berdasarkan PP RI Nomor: 19 Tahun 2005, yang diubah menjadi PP RI No 32 tahun 2015 tentang: Standar Nasional Pendidikan, dengan komponen-komponen mutu kegiatan akademik. Pertama, Standar Nasional Pendidikan yaitu: (1) Isi Pendidikan, (2) Proses Pembelajaran, (3) Kompetensi Lulusan, (4) Pendidik dan Tenaga Kependidikan, (5) Sarana dan Prasarana, (6) Pengelolaan,

Pembiayaan, (8) Penilaian Pendidikan dan kedua, Standar melampaui SNP yaitu: (9) Penelitian, (10) Kerja Sama, (11) Mahasiswa, (12) Manajemen Lembaga, (13) Tata Pamong/Tata Kelola, (14) Pengabdian pada Masyarakat, (15) Suasana Akademik, dan (16) Sistem Informasi.

\section{PENUTUP}

Berdasarkan hasil penelitian yang telah dikemukakan maka terdapat beberapa kesimpulan sebagai berikut:

1. Tingkat kualifikasi akademik dosen di Universitas Muhammadiyah Makassar berdasarkan indikator: jenjang pendidikan $(65,46 \%)$ penguasaan materi $(79,5 \%)$ metode $(73,1 \%)$ media 
dan sumber belajar $(92,8 \%)$ dan kemampuan interaksi edukatif dalam Proses Belajar Mengajar (98,8\%) hal ini berarti tingkat kualifikasi akademik dosen di Unismuh Makassar berkategori sedang.

2. Tingkat prestasi akademik dosen di Unismuh Makassar berdasarkan indikator: kemampuan lisan $(73,5 \%)$ kemampuan tulisan (40, 67\%), keterampilan $(54,52 \%)$ pencapaian reputasi/prestasi $(41, \quad 55 \%)$ dan kemampuan pemecahan masalah $(53 \%)$ yang berarti berada pada kategori sedang.

3. Mutu pembelajaran di Unismuh Makassar berdasarkan indikator: Input (81, 9\%), Proses, $(80,42 \%)$ Output $(65 \%)$ dan Outcome $(62,6 \%)$ berada pada kategori sedang.

4. Tidak terdapat pengaruh yang signifikan antara kualifikasi akademik dosen terhadap mutu pembelajaran di Universitas Muhammadiyah Makassar. Hal ini dapat dilihat dari nilai signifikansi $0.502<1,66$ yang artinya H1 ditolak dan H0 diterimah artinya tidak terdapat pengaruh antara 2 (dua) variabel.

5. Terdapat pengaruh yang signifikan prestasi akademik dosen terhadap mutu pembelajaran dengan nilai $0.003<0,05$ yang artinya $\mathrm{H}_{0}$ diterima dan $\mathrm{H}_{1}$ diterimah. Dengan demikian terdapat pengaruh antara 2 (dua) variabel.

\section{DAFTAR PUSTAKA}

Abbas, Syahruizal. Manajemen Perguruan Tinggi. Cet. 2; Jakarta: Kencana Prenada Media Group, 2009

Departemen Agama RI. Al-Qur'anul Karim Terjemah Tajwid Berwarna. Jakarta: Jabal Raudhotul Jannah, 2009

Departemen Pendidikan Nasional. Pedoman Penjaminan Mutu (Quality Acssurance Pendidikan Tinggi) Direktorat Jenderal Pendidikan Tinggi 2003

Undang-Undang Sistem Pendidikan Nasional. Cet. IV; Yogyakarta: Pustaka Pelajar, 2011 tahun 2015 tentang Standar Nasional Pendidikan Tingg. Depdiknas, 2015

H.Besterfield. Total Quality Management. Third edition, Prentice Hali, 2003

Http:///www.bps.go.id. diakses, tanggal, 10 Mei 2018

Shihab, M. Quraish. Tafsir Al-Misbah: Pesan, Kesan dan Kerahasiaan AlQuran. Vol. 14; Jakarta: Lentera Hati, 2006

Sukmadinata. Nana Syaodih. Metode Penenlitian Pendidikan. Cet.IV; Bandung: Remaja Rosdakarya, 2008

Sobur. Psikologi Umum. Bandung: Pustaka Setia, 2006. 
Unismuh Makassar, Sumber Data PDPT Unismuh Makassar 2017/2018. Unismuh Makassar, 2018

\section{Pidato Rektor}

Unismuh Makassar pada wisuda ke 65, 9 Juli 2018. Unismuh Makassar, 2018
Laporan Rektor pada Raker Unismuh Makassar T.A. 2018-2019. Unismuh Makassar, 2018

\section{Standar 5 Borang} Akreditasi Unismuh Makassar tahun 2017. Unismuh Makassar, 2007 